\title{
Unusual iridoid glycosides in Veronica sects. Hebe and Labiatoides
}

\author{
Jensen, Søren Rosendal
}

Published in:

Biochemical Systematics and Ecology

Link to article, DOI:

10.1016/j.bse.2007.09.011

Publication date:

2008

Document Version

Early version, also known as pre-print

Link back to DTU Orbit

Citation (APA):

Jensen, S. R. (2008). Unusual iridoid glycosides in Veronica sects. Hebe and Labiatoides. Biochemical Systematics and Ecology, 36(3), 207-215. https://doi.org/10.1016/j.bse.2007.09.011

\section{General rights}

Copyright and moral rights for the publications made accessible in the public portal are retained by the authors and/or other copyright owners and it is a condition of accessing publications that users recognise and abide by the legal requirements associated with these rights.

- Users may download and print one copy of any publication from the public portal for the purpose of private study or research.

- You may not further distribute the material or use it for any profit-making activity or commercial gain

- You may freely distribute the URL identifying the publication in the public portal

If you believe that this document breaches copyright please contact us providing details, and we will remove access to the work immediately and investigate your claim 
Unusual iridoid glycosides in Veronica sects. Hebe and Labiatoides

\author{
Søren Rosendal Jensen ${ }^{\mathrm{a},{ }^{*}}$, Charlotte Held Gotfredsen, ${ }^{\mathrm{a}}$ Renée J. Grayer ${ }^{\mathrm{b}}$ \\ ${ }^{a}$ Department of Chemistry, The Technical University of Denmark, DK-2800, \\ Lyngby, Denmark \\ ${ }^{\text {b} R o y a l ~ B o t a n i c ~ G a r d e n s, ~ K e w, ~ R i c h m o n d, ~ S u r r e y, ~ T W 9 ~ 3 A B, ~ U K ~}$
}

Dedicated to the memory of Prof. Dr. Robert Hegnauer, 1919-2007

Corresponding author. Tel.: +45-45252103; fax: $+45-45933968$.

E-mail address: srj@kemi.dtu.dk (S.R. Jensen). 


\begin{abstract}
In a chemosystematic investigation of three Southern hemisphere species of Veronica, namely the Australian $V$. derwentiana Andrews and $V$. perfoliata R.Br. (formerly Derwentia species), and the New Zealand $V$. catarractae G. Forster (formerly a species of Parahebe), the water-soluble constituents were isolated and identified by spectroscopic methods. Apart from other iridoid glucosides common to the genus, three unusual substituted benzoyl esters of aucubin (derwentiosides A-C) were obtained from $V$. derwentiana and a chlorinated iridoid glycoside (catarractoside) from $V$. catarractae in addition to other iridoids common to the genus. The chemical profile of $V$. perfoliata is similar to that of Northern hemisphere species of Veronica because of the presence of characteristic 6-O-catalpol esters. The profile of $V$. derwentiana is unique, since 6-O-esters of aucubin rather than of catalpol dominate, however, the acyl groups are the same as those present in catalpol esters found in some other Veronica sections. V. catarractae also contains one of the catalpol esters characteristic of Veronica, but in addition three 6-O-rhamnopyranosyl substituted iridoid glycosides, one of which is 6-O-rhamnopyranosylcatalpol. Esters of the latter compound are previously only known from the more derived species in recent phylogenetic trees of sect. Hebe to which $V$. catarractae now also belongs, but as a more basal member.
\end{abstract}

Keywords: Chemosystematics; Veronica derwentiana; V. perfoliata; V. catarractae; Derwentia; Parahebe; Plantaginaceae; Mannitol; Iridoid glucosides; 6-O-Aucubin esters; 6-O-Rhamnopyranosyl iridoids. 


\section{Introduction}

Veronica L. sensu lato is a large genus of ca. 500 species with centres of diversity in both the Northern and Southern hemisphere. The genus now belongs to the family Plantaginaceae after its traditional family Scrophulariaceae was split up on the basis of molecular evidence (Olmstead and Reeves, 1995; Olmstead et al., 2001, APG, 2003; Albach et al., 2005a; Oxelman et al., 2005). In the course of the $20^{\text {th }}$ century the Veronica species of the Southern hemisphere were nearly all transferred to a number of new or revived genera, the largest of which were Hebe Benth. and Parahebe Oliver, which comprised mainly New Zealand species. Briggs and Ehrendorfer (1968) observed that some of the Australian species of Veronica were closer to Parahebe than to Eurasian species of Veronica and therefore transferred them to Parahebe. Later they transferred most of the Australian Parahebe species to the revived genus Derwentia Raf. (Briggs and Ehrendorfer, 1992). However, recently on the basis of cladistic analyses of nucleic acid sequence data it became clear that the Southern hemisphere genera are nested within Veronica and that recognition of these taxa would make Veronica paraphyletic (Albach and Chase, 2001; 2004; Wagstaff et al., 2002; Albach et al., 2005b). Therefore, all the Southern hemisphere species have now been transferred back to Veronica (Garnock-Jones et al., 2007).

Veronica derwentiana Andrews (synonyms Derwentia derwentiana B. Briggs et Ehrend. and Parahebe derwentiana B. Briggs et Ehrend.) and V. perfoliata R. Br. (synonyms D. perfoliata B. Briggs et Ehrend. and P. perfoliata B. Briggs et Ehrend.) are two Australian species which have now been placed in Veronica sect. Labiatoides Wettst. (Garnock-Jones et al., 2007). V. derwentiana, which has white flowers, is 
found in a number of plant communities from eucalypt forests to alpine herb fields, whereas $V$. perfoliata or "digger's speedwell" has blue flowers and grows in similar but slightly dryer habitats (Harden, 1992). V. catarractae G. Forster (synonym Parahebe catarractae Oliver), which has been placed in Veronica section Hebe (Juss.) G. Don, grows on the South Island of New Zealand. The flowers are usually white with pink or purple veins. $V$. perfoliata and $V$. catarractae are currently cultivated as garden plants in the UK. Recently we have carried out several iridoid surveys in Eurasian species of Veronica (Jensen et al., 2005) and in New Zealand species formerly belonging to the genus Hebe (Johansen et al., 2007; Pedersen et al., in print). Therefore we were interested to see how the iridoid profiles of $V$. derwentiana, $V$. perfoliata and $V$. catarractae (formerly belonging to the genera Derwentia and Parahebe) would compare. Although more than 30 years ago extracts of these three species were analysed for the presence of iridoids and flavonoids during paper chromatographic surveys of the genus Veronica (Grayer-Barkmeijer, 1973; 1978; 1979), no iridoids were isolated for a more accurate identification. During the present survey, three new iridoid esters were obtained from $V$. derwentiana, and also a new iridoid glycoside from $V$. catarractae.

\section{Materials and Methods}

\subsection{General}

Fresh plant material (23-31 g) was emersed in boiling EtOH (4 x weight), liquidized after cooling and filtered. The concentrated extracts were partitioned in $\mathrm{Et}_{2} \mathrm{O}-\mathrm{H}_{2} \mathrm{O}$. The aqueous phase was taken to dryness, and separated by reverse phase preparative chromatography. Merck Lobar RP-18 columns (size B) were eluted with $\mathrm{H}_{2} \mathrm{O}-\mathrm{MeOH}$ mixt. (1:0 to 1:1); compounds are listed in order of elution; the amount of mannitol 
(21) was estimated from the ${ }^{13} \mathrm{C}$ NMR spectrum of the crude sugar fraction. NMR Spectra were recorded on a Varian Unity Inova-500 MHz $\left({ }^{1} \mathrm{H}\right)$ or Mercury-300 MHz $\left({ }^{13} \mathrm{C}\right)$ instruments in $\mathrm{MeOH}-d_{4}$ using the solvent peak $(\delta 3.31$ or 49.0$)$ as the internal standard; In the cases where ${ }^{13} \mathrm{C}$ NMR spectra were recorded in $\mathrm{D}_{2} \mathrm{O}$ the $\mathrm{C}-6$ ' shift was set to 61.5 ppm (Damtoft et al., 1981). 2D DQF-COSY, gHSQC, HMBC and NOESY spectra were acquired using standard pulse sequences. LC-HR ESIMS was performed on an Agilent HP 1100 Liquid Chromatograph equipped with a BDS-C18 reversed phase column running a water-acetonitrile (50 ppm TFA in water) gradient. The LC was coupled to a LCT of a TOF MS (Micromass, Manchester, UK) operated in the positive electrospray ion mode using 5-leucineenkephalin as lock mass. The known compounds isolated were identified by their NMR data: mannitol (21), (Bock and Pedersen, 1983); and iridoids (1-4, 6, 11) (Rønsted et al., 2000); erinoside (5) (Taskova et al., 2005); sinuatol (10; 6-O-rhamnopyranosylaucubin) (Bianco et al.; 1981); verproside (12) (Afifi-Yazar and Sticher, 1980); specioside (13) (El-Naggar, and Doskotch, 1980); verminoside (14) and minecoside (15) (Sticher and Afifi-Yazar, 1979); 6-O-rhamnopyranosylcatalpol (16) (Helfrich and Rimpler; 1999);

scrophularioside (19) (Sticher et al., 1980); persicoside (22) (Harput et al., 2002); epiaucubin (Bianco et al., 1983);

\subsection{Plant material}

A specimen of $V$. derwentiana (voucher no. BI 16376) was grown in c.1970 from seeds obtained from the National Botanical Gardens at Canberra, Australia, in the garden of the Lab. for Experimental Plant Systematics, University of Leiden, The Netherlands. In 1983 the plant was transferred to the garden of one of the authors (R.J.G.). V. perfoliata (voucher no. BI 16377) and V. catarractae (voucher no. BI 
16378) were also grown and identified by R.J.G., but are of garden origin. Voucher specimens have been deposited in the Herbarium of the Royal Botanic Gardens, Kew $(\mathrm{K})$.

\subsubsection{V. derwentiana}

The aq. extract (2.6 g from $30 \mathrm{~g}$ leaves and stems) was dissolved in $10 \%$ HOAc and chromatographed on a B-column eluting with $\mathrm{H}_{2} \mathrm{O}-\mathrm{MeOH}$ mixt. (1:0 to 1:1) to give: carbohydrates (390 mg; 90\% mannitol; 21), a mixt. of aucubin and epiaucubin (2:1; $20 \mathrm{mg})$, aucubin $(6 ; 120 \mathrm{mg})$, gardoside $(\mathbf{3} ; 10 \mathrm{mg})$, a 3:1 mixt. of mussaenosidic acid (1) and epiloganic acid (2) (90 mg), a fract. A (580 mg), scrophularioside (19; 100 $\mathrm{mg}$ ) and derwentioside A (7; $530 \mathrm{mg})$. Fract. A was rechromatographed to give derwentioside B (8; $40 \mathrm{mg})$ and derwentioside C (9; $400 \mathrm{mg})$.

\subsubsection{V. perfoliata.}

The aq. extract ( $1.4 \mathrm{~g}$ from $18 \mathrm{~g}$ leaves and stems) was chromatographed as above to give: sugars etc. (280 mg; 90\% mannitol; 21), catalpol (11; $20 \mathrm{mg})$, aucubin $(\mathbf{6} ; 10$ mg), picein (20a; $50 \mathrm{mg})$, arborescosidic acid (4; $10 \mathrm{mg})$, erinoside (5; $11 \mathrm{mg})$, verproside (12; $160 \mathrm{mg})$, persicoside (22; $60 \mathrm{mg})$, verminoside (14; $280 \mathrm{mg})$, specioside (13; $40 \mathrm{mg})$ and minecoside $(\mathbf{1 5} ; 40 \mathrm{mg})$.

\subsubsection{V. catarractae}

The aq. extract ( $1.0 \mathrm{~g}$ from $21 \mathrm{~g}$ leaves and stems) was dissolved in $\mathrm{H}_{2} \mathrm{O}$ and chromatographed as above to give: sugars etc. (165 mg; 90\% mannitol; 21), a fraction with mainly gardoside $(3 ; 40 \mathrm{mg})$, catalpol (70 mg), 6-O-rhamnopyranosylcatalpol (16; $60 \mathrm{mg})$, aucubin $(6 ; 60 \mathrm{mg})$, catarractoside $(\mathbf{1 8} ; 10 \mathrm{mg})$, sinuatol (10; 6-O- 
rhamnopyranosylaucubin; $50 \mathrm{mg}$ ), pungenin (20b; $90 \mathrm{mg})$, inseparable mixture of mainly CPGs (130 mg) and verminoside (14; $200 \mathrm{mg})$.

\subsubsection{Derwentioside A (6-O-benzoylaucubin; 7)}

Amorphous solid; $[\alpha]_{\mathrm{D}}^{23}=-198^{\circ}(\mathrm{MeOH} ; c$ 0.6); LC-HR ESIMS $m / z: 468.1886$

$\left[\mathrm{M}+\mathrm{NH}_{4}\right]^{+} ;\left(\mathrm{C}_{22} \mathrm{H}_{30} \mathrm{NO}_{10}\right.$ requires 468.1870$) ;{ }^{1} \mathrm{H}$ and ${ }^{13} \mathrm{C}$ NMR data in Table 1.

\subsubsection{Derwentioside B (6-O-p-hydroxybenzoylaucubin; 8)}

Amorphous solid; $[\alpha]_{\mathrm{D}}^{23}=-179^{\circ}(\mathrm{MeOH} ; c$ 0.4); LC-HR ESIMS $m / z: 484.1824$

$\left[\mathrm{M}+\mathrm{NH}_{4}\right]^{+} ;\left(\mathrm{C}_{22} \mathrm{H}_{30} \mathrm{NO}_{11}\right.$ requires 484.1819$) ;{ }^{1} \mathrm{H}$ and ${ }^{13} \mathrm{C}$ NMR data in Table 1.

\subsubsection{Derwentioside C (6-O-vanilloylaucubin; 9)}

Amorphous solid; $[\alpha]_{\mathrm{D}}^{23}=-170^{\circ}(\mathrm{MeOH} ; c$ 0.2); LC-HR ESIMS $m / z: 514.1917$

$\left[\mathrm{M}+\mathrm{NH}_{4}\right]^{+} ;\left(\mathrm{C}_{23} \mathrm{H}_{32} \mathrm{NO}_{12}\right.$ requires 514.1925$) ;{ }^{1} \mathrm{H}$ and ${ }^{13} \mathrm{C}$ NMR data in Table 1.

\subsubsection{Catarractoside (6-O-rhamnopyranosylasystasioside E; 18)}

Could only be purified to an amorphous solid of ca $90 \%$ purity according to NMR, therefore no optical rotation was recorded. LC-HR ESIMS m/z: $562.1917\left[\mathrm{M}+\mathrm{NH}_{4}\right]^{+}$; $\left(\mathrm{C}_{21} \mathrm{H}_{37} \mathrm{NO}_{14} \mathrm{Cl}\right.$ requires 562.1903); NMR data in Table 2.

\subsubsection{Pungenin (20b)}

Crystals from MeOH; m.p. 189-192 [lit. 188-195º (Strunz et al., 1986)]; LC-HR ESIMS $m / z: 315.1088[\mathrm{M}+\mathrm{H}]^{+} ;\left(\mathrm{C}_{14} \mathrm{H}_{19} \mathrm{O}_{8}\right.$ requires 315.1080$) ;{ }^{1} \mathrm{H} \mathrm{NMR}\left(\mathrm{MeOH}-d_{4}\right): \delta$ 
$7.84(d, 2.0 ; \mathrm{H}-2) ; 6.90(d, 8.4 ; \mathrm{H}-5) ; 7.64(d d, 8.4,2.0 ; \mathrm{H}-6) ; 2.52(s ; \mathrm{Me}) ; 4.84(d$, 7.6; H-1'); 3.52 (dd, 9.1, 7.6; H-2'); 3.40 (t-like, 9; H-3'); 3.48 (2H, obsc.; H-4', H-5'); $3.72\left(d d, 12.1,5.6 ; \mathrm{H}-6 \mathrm{a}^{\prime}\right) ; 3.91\left(d d, 12.1,2.0 ; \mathrm{H}-6 \mathrm{~b}^{\prime}\right) .{ }^{13} \mathrm{C} \mathrm{NMR}\left(\mathrm{MeOH}-d_{4}\right): \delta 130.4$ (C-1); 118.9 (C-2); 154.1 (C-3); 146.6 (C-4); 117.0 (C-5); 126.4 (C-6); 199.4 (CO); $26.4(\mathrm{Me}) ; 104.0\left(\mathrm{C}^{-1} 1^{\prime}\right) ; 74.8$ (C-2'); $77.5\left(\mathrm{C}-3^{\prime}\right) ; 71.3$ (C-4'); 78.4 (C-5'); 62.4(C-6').

\section{Results and Discussion}

The plant material was briefly boiled with ethanol and after extraction, the watersoluble part of the extract was subjected to reverse phase column chromatography and the isolated compounds were characterized by their NMR spectra (see section 3.1). Mannitol (21) was the main carbohydrate in all species investigated. The two Australian species from section Labiatoides, namely the closely related $V$. derwentiana and $V$. perfoliata were otherwise completely different in chemical garniture. From the former the following iridoid acids were isolated: mussaenosidic acid (1), 8-epiloganic acid (2) and gardoside (3) together with aucubin (6), the aucubin ester scrophularioside (19) and in addition three new esters of aucubin (7-9).

Compound 7 had the elemental composition $\mathrm{C}_{22} \mathrm{H}_{26} \mathrm{O}_{10}$ as established by HR-ESIMS. The NMR spectra of 7 in methanol- $d_{4}$ (Table 1) were assigned by the usual 2D techniques and the ${ }^{13} \mathrm{C}$ NMR spectrum showed only twenty signals of which two were of double intensity. A set of six peaks could be assigned to a $\beta$-glucopyranosyl moiety, another set (of five, including those of double intensity) represented a benzoyl group while the remaining nine signals represented an iridoid aglucone very similar to aucubin (6), except that the signals assigned to C-6 and C-7 were seen 3-5 ppm downfield and those from C-5 and C-8 were moved upfield when compared to those 
of 6. This indicated that the C-6 oxygen atom was esterified with the benzoyl group. Inspection of the ${ }^{1} \mathrm{H}$ NMR spectrum confirmed that this was indeed the case since the H-6 signal was seen at $\delta_{\mathrm{H}} 5.57$, more than $1 \mathrm{ppm}$ downfield from that seen in the spectrum of 6. Further proof was obtained from the HMBC spectrum where a (weak) correlation was seen between $\mathrm{H}-6\left(\delta_{\mathrm{H}} 5.57\right)$ and the carbonyl carbon atom of the benzoyl group $\left(\delta_{\mathrm{C}} 167.9\right)$. Compound 7 was therefore 6-O-benzoylaucubin, and we have named it derwentioside A.

The elemental composition of compound $\mathbf{8}$ was determined to be $\mathrm{C}_{22} \mathrm{H}_{26} \mathrm{O}_{11}$ by HRESIMS. The NMR spectra in methanol- $d_{4}$ (Table 1) were assigned as above and were very similar to those of 7, except for the aromatic part, which obviously had to be a $p$ substituted system. Due to the symmetry, the ${ }^{13} \mathrm{C}$ NMR spectrum showed twenty signals of which two were of double intensity. As above, 15 of the signals could be assigned to a substituted aucubin (6) moiety, and the remaining set could be interpreted as a p-hydroxybenzoyl group. In the ${ }^{1} \mathrm{H}$ NMR spectrum, the low field position of the signal from $\mathrm{H}-6\left(\delta_{\mathrm{H}} 5.51\right)$, when compared to the spectrum of $\mathbf{6}$, again indicated that this was the point of acylation in $\mathbf{8}$. Proof was obtained from the HMBC spectrum, where the expected correlation was seen between $\mathrm{H}-6\left(\delta_{\mathrm{H}} 5.51\right)$ and the carbonyl carbon atom of the benzoyl group $\left(\delta_{\mathrm{C}} 168.0\right)$. Compound 8 was therefore 6$O$-p-hydroxybenzoylaucubin, and we have named it derwentioside B.

Compound 9 had the elemental composition $\mathrm{C}_{23} \mathrm{H}_{28} \mathrm{O}_{12}$ as established by HR-ESIMS. The NMR spectra of 9 in methanol- $d_{4}$ (Table 1) were assigned as above and by comparison with the spectra of $\mathbf{7}$ and $\mathbf{8}$ it could be shown to contain a 6-O-substituted aucubin moiety. Of the remaining eight signals in the ${ }^{13} \mathrm{C}$ NMR spectrum, seven could 
be assigned to a benzoyl group substituted in the 3- and 4-positions with oxygen atoms. The last signal $\left(\delta_{\mathrm{C}} 56.3\right)$ proved to be a methoxy group. This indicated the presence of either a vanilloyl or an isovanilloyl moiety in 9, however, comparison with known examples, namely the spectra of amphicoside (vanilloylcatalpol; Kapoor et al., 1971) and isovanilloylcatalpol (Özipek et al., 1998), the best fit was found with the former. This was confirmed by the HMBC spectrum, where the $O$-methyl group showed only one correlation, namely to the signal at $\delta_{\mathrm{C}} 148.5$ assigning this as the methoxylated carbon atom. Secondly, the H-5" signal $\left(\delta_{\mathrm{H}} 6.82\right)$ had two strong correlations to the meta-carbon atoms ( $\delta_{\mathrm{C}} 122.4$ and the above $\left.\delta_{\mathrm{C}} 148.5\right)$, of which the former was assigned to $\mathrm{C}-1$ " and the latter similarly had to be $\mathrm{C}-3$ ". This proved that the acid residue was a vanilloyl group. Compound 9 was therefore 6-Ovanilloylaucubin, and we have named it derwentioside $\mathrm{C}$.

$V$. perfoliata also contained iridoid acids, but in this case they were arborescosidic acid (4) and erinoside (5). The remaining compounds were all known from other species of Veronica: aucubin (6), catalpol (11) and four esters of the latter, namely verproside (12), specioside (13), verminoside (14) and minecoside (15), together with the acetophenone glucoside picein (20a) and the caffeoyl phenylethanoid glycoside (CPG) persicoside (22).

The last species investigated, namely the New Zealand $V$. catarractae, belonging to section Hebe, was rather unlike the other species in the glucosides present. It did contain gardoside (3), aucubin (6), catalpol (11) and verminoside (14) as well as the acetophenone glucoside pungenin (20b), but it also had three 6-O- 
rhamnopyranosylsubstituted iridoids, namely 10 (sinuatol), 16 and 18, of which the last one had so far not been described in the literature.

Compound (18) was only isolated in an impure state; however, satisfactory spectroscopic data could be obtained. The elemental composition was $\mathrm{C}_{21} \mathrm{H}_{33} \mathrm{O}_{14} \mathrm{Cl}$ as established by HRESIMS (the presence of chlorine in the molecule was confirmed by the $\mathrm{M}+2$ peak in the spectrum). The NMR spectra of $\mathbf{1 8}$ in methanol- $d_{4}$ (Table 2) were assigned by the usual 2D techniques and the ${ }^{13} \mathrm{C}$ NMR spectrum showed the expected 21 signals of which six could be assigned to a $\beta$-glucopyranosyl moiety, another set of six to an $\alpha$-rhamnopyranosyl group while the remaining nine signals were in accordance with a chlorine containing iridoid aglucone. Comparison of the NMR spectra (Table 2) with those reported (in $\mathrm{D}_{2} \mathrm{O}$ ) for asystasioside E (17; Demuth et al., 1989) showed a convincing similarity, the ${ }^{1} \mathrm{H}$ signals being within $0.1 \mathrm{ppm}$ of those reported while the ${ }^{13} \mathrm{C}$ were less similar. Thus, the $\mathrm{C}-6$ signal was about 8 ppm downfield from that of $\mathbf{1 7}$, indicating that the $\alpha$-rhamnopyranosyl group was attached at the C- 6 oxygen. The HMBC spectrum showed a significant correlation between the $\mathrm{H}-1 "\left(\delta_{\mathrm{H}} 4.91\right)$ and C-6 signal $\left(\delta_{\mathrm{C}} 89.7\right)$, likewise, a correlation was seen between the H-1' $\left(\delta_{\mathrm{H}} 4.64\right)$ and C-1 signal $\left(\delta_{\mathrm{C}} 93.0\right)$, proving the respective points of attachment for the sugar residues as that shown in the formula 18. The compound is therefore 6$O$-rhamnopyranosyl asystasioside E, and we have named it catarractoside.

Regarding the acetophenone glucoside pungenin (20b), this compound had not been reported from Veronica before. Only incomplete NMR data were published for $\mathbf{2 0 b}$ (Strunz et al., 1986), and in order to properly identify this compound, we recorded the NMR spectra (see 2.2.8) including a set of 2D spectra. The ${ }^{1} \mathrm{H}$ NMR spectrum was 
reminiscent of that of picein (20a), but it clearly showed that an extra substituent was present in the 3-position of the aromatic nucleus. The remaining question was now the position of the $\beta$-glucopyranosyl moiety. This was resolved by the NOESY spectrum in which a significant correlation was seen between the H-1' $\left(\delta_{\mathrm{H}} 4.84\right)$ and the H-2 signal $\left(\delta_{\mathrm{H}} 7.84\right)$, settling the sugar moiety to be at the O-3 position as in pungenin.

The results from the present investigation confirm that the members of Veronica sect. Hebe and Labiatoides are much more variable in glycoside content than those of Northern Hemisphere origin. Particularly remarkable are the lack of catalpol (11) and the presence of three 6-O-aucubin esters (7-9) in $V$. derwentiana. Such aucubin esters are unusual in the genus and even in Plantaginaceae; only in a single case has a similar compound been found, namely the compound 6-O-(3,4-dihydroxybenzoyl)aucubin (topiarioside) from V. topiaria (L. B. Moore) Garn.-Jones (Pedersen et al., in print). Conversely, similar 6-O-catalpol esters with substituted benzoic acids are very common in most sections of Veronica, and this could be seen as a deviation from the normal biosynthetic pathway found in the genus in $V$. derwentiana. In other families such 6-O-aucubin esters are also rare, having been reported only from a few genera in Orobanchaceae (3), Scrophulariaceae (2) and Utriculariaceae (1) (see Pedersen et al., in print).

The finding of the two acetophenone glucosides $20 \mathbf{a}$ and $20 \mathbf{b}$ in $V$. perfoliata and $V$. catarractae, respectively, is perhaps not surprising. Picein (20a) is also known from $V$. bellidioides L. (Taskova et al., 1998) and from a $V$. odora hybrid together with the related androsin, although neither was present in $V$. odora Hook. f. itself (Johansen et al., 2007). Pungenin (20b) is here reported for the first time in the genus, it has 
previously only been found in Pinaceae. Otherwise, acetophenone glucosides are not uncommon in angiosperms; in Plantaginaceae, 20a has been reported from both species of Picrorhiza (Stuppner and Wagner, 1989; Wang et al., 2004), one species of Globularia (Calis et al., 2002), and four species of Penstemon (Junior, 1984; 1986; Stermitz et al., 1993; Vesper and Seifert, 1994). However, due to its occasional occurrence, picein shows limited chemosystematic promise.

Chlorinated iridoid glucosides like catarractoside (18) are of sporadic occurrence. They seem to be biosynthetically derived from the corresponding epoxides (i.e. 16 or 11), since they apparently always occur together with these. Previously, the parent asystasioside E (17) has been found in the related Wulfenia baldaccii Degen together with its 6-O-cinnamoylester (Taskova et al., 2006).

The presence of iridoid glucosides with a 6-O-rhamnopyranosyl substituent, particularly 6-O-rhamnopyranosylcatalpol (16) in $V$. catarractae, is notable. Compound 16 and its esters are systematically interesting, and we have demonstrated (Pedersen et al., in print) that of the investigated taxa belonging to sect. Hebe, only the most derived species in recent phylogenetic trees (Wagstaff et al., 2002) contain esters of $\mathbf{1 6}$ as the more basal species apparently lacked them. The finding of the parent 6-Orhamnopyranosylcatalpol (16) in $V$. catarractae is therefore not in conflict with this conclusion since itb also belongs to the latter group. Notably, the incidence of $\mathbf{1 6}$ in a plant has apparently not been reported before without the concurrent presence of one or more of its esters. The distribution of these esters is so far confined to three families: Scrophulariaceae (many genera), Verbenaceae (four genera) and recently also Plantaginaceae. In the latter they are only known from Erinus (Taskova et al., 
2005), and four genera in Veroniceae, namely Veronica sect. Hebe, Veronicastrum (Taskova et al., 2006), Scrofella (Sun et al., 2006) and Lagotis (Yang et al., 2007). The three latter are all from the same clade in Veroniceae (Albach et al., 2004).

\section{Acknowledgement}

We thank Kristian Fog Nielsen, BioCentrum, DTU, for recording the mass spectra.

\section{References}

Afifi-Yazar, F. U., Sticher, O., 1980. Verproside, a new iridoid glucoside from Veronica officinalis L. (Scrophulariaceae). Helv. Chim. Acta 63, 1905-1907.

Albach, D. C., Chase, M. W., 2001. Paraphyly of Veronica (Veroniceae; Scrophulariaceae): evidence from the internal transcribed spacer (ITS) sequences of nuclear ribosomal DNA. J. Plant Res. 114, 9-18.

Albach, D. C., Chase, M. W., 2004. Incongruence in Veroniceae (Plantaginaceae): evidence from two plastid and a nuclear ribosomal DNA region. Mol. Phylog. Evol. 32, 183-197.

Albach, D. C., Martínez-Ortega, M. M., Fischer, M. A., Chase, M. W., 2004. A new classification of the tribe Veroniceae - problems and a possible solution. Taxon 53, 429-452.

Albach, D. C., Meudt, H. M., Oxelman, B., 2005a. Piecing together the "new" 
Plantaginaceae. Am. J. Bot. 92, 297-315.

Albach, D. C., Utteridge, T., Wagstaff, S. J., 2005b. Origin of Veroniceae

(Plantaginaceae, formerly Scrophulariaceae) on New Guinea. Syst. Bot. 30, 412-423.

APG (Angiosperm Phylogeny Group), 2003. An update of the Angiosperm Phylogeny Group classification for the orders and families of flowering plants: APG II. Bot. J. Linn. Soc. 141, 399-436.

Bianco, A., Guiso, M., Iavarone, C., Passacantilli, P., Trogolo, C., 1981. Iridoids. XXIX. Sinuatol (6-O- $\alpha$-L-rhamnopyranosylaucubin) from Verbascum sinuatum. Planta Med. 41, 75-79.

Bianco, A., Passacantilli, P., Polidori, G., Nicoletti, M., Messana, I., 1983. NMR spectroscopy of epimeric pairs of glucosidic iridoids. Gazz. Chim. Ital. 113, 829-834.

Bock, K., Pedersen, C., 1983. Carbon-13 nuclear magnetic resonance spectroscopy of monosaccharides. Adv. Carbohydrate Chem. Biochem. 41, 27-66.

Briggs, B. G., Ehrendorfer, F., 1968. New combinations in Parahebe. Taxon 17, 742.

Briggs, B. G., Ehrendorfer, F., 1992. A revision of the Australian species of Parahebe and Derwentia (Scrophulariaceae). Telopea 5, 241-287. 
Calis, I., Kirmizibekmez, H., Tasdemir, D., Sticher, O., Ireland, C. M., 2002. Sugar esters from Globularia orientalis. Z. Naturforsch. 57C, 591-596.

Damtoft, S., Jensen, S. R., Nielsen, B. J., 1981. ${ }^{13} \mathrm{C}$ and ${ }^{1} \mathrm{H}$ NMR spectroscopy as a tool in the configurational analysis of iridoid glucosides. Phytochemistry 20, $2717-2732$.

Demuth, H., Jensen, S. R., Nielsen, B. J., 1989. Iridoid glucosides from Asystasia bella. Phytochemistry 28, 3361-3364.

El-Naggar, S., Doskotch, R. W., 1980. Specioside: a new iridoid glycoside from Catalpa speciosa. J. Nat. Prod. 43, 524-526.

Garnock-Jones, P. J., Albach, D. C., Briggs, B. G., 2007. Botanical names in Southern Hemisphere Veronica (Plantaginaceae): sect. Detzneria, sect. Hebe, and sect. Labiatoides. Taxon 56, 571-582.

Grayer-Barkmeijer, R. J., 1973. A chemotaxonomic study of Veronica: Iridoid glucosides. Biochem. Syst. 1, 101-110.

Grayer-Barkmeijer, R. J., 1978. Flavonoids in Parahebe and Veronica: A chemotaxonomic study. Biochem. Syst. Ecol. 6, 131-137.

Grayer-Barkmeijer, R. J., 1979. Chemosystematic investigations in Veronica L. 
(Scrophulariaceae) and related genera. $\mathrm{PhD}$ Thesis, Univ. of Leiden, The Netherlands.

Harden, G. J. (ed.), 1992. Flora of New South Wales, vol. 3. New South Wales Univ. Press, Kensington.

Harput, U. S., Saracoglu, I., Inoue, M., Ogihara, Y., 2002. Phenylethanoid and iridoid glycosides from Veronica persica. Chem. Pharm. Bull. 50, 869-871.

Helfrich, E., Rimpler, H., 1999. Iridoid glycosides and phenolic glycosides from Holmskioldia sanguinea. Phytochemistry 50, 619-627.

Jensen, S. R., Albach, D. C., Ohno, T., Grayer, R. J., 2005. Veronica: Iridoids and cornoside as chemosystematic markers. Biochem. Syst. Ecol. 33, 1031-1047.

Johansen, M., Larsen, T. S., Mattebjerg, M. A., Gotfredsen, C. H., Jensen, S. R. 2007. Chemical markers in Veronica sect. Hebe. Biochem. Syst. Ecol. 35, 614-620.

Junior, P. 1984. Iridoid glucosides and an acetophenone glucoside from Penstemon whippleanus. Planta Med. 50, 444-445.

Junior, P. 1986. Acetophenone glucosides from Penstemon pinifolius. Planta Med. 52, 218-220.

Kapoor, S. K.; Kohli, J. M.; Zaman, A., 1971. Amphicoside. I. New bitter glycoside 
from Amphicome emodi. Tetr. Letters 2839-40.

Olmstead, R.G., Reeves, P.A., 1995. Polyphyletic origin of the Scrophulariaceae: evidence from $r b c \mathrm{~L}$ and $n d h \mathrm{~F}$ sequences. Ann. Missouri Bot. Gard. 82, 176193.

Olmstead, R. G., DePamphilis, C. W., Wolfe, A. D., Young, N. D., Elisons, W. J., Reeves, P. A., 2001. Disintegration of the Scrophulariaceae. Am. J. Bot. 88, $348-361$.

Oxelman, B., Kornhall, P., Olmstead, R. G., Bremer. B., 2005. Further disintegration of Scrophulariaceae. Taxon 54, 411-426.

Ozipek, M., Saracoglu, I., Maruyama, M., Takeda, T., Calis, I., 1998 Iridoid glucosides from Veronica fuhsii. Hacettepe Univ. J. Fac. Pharm. 18, 9-14.

Pedersen, P., Gotfredsen, C. H., Wagstaff, S. J., Jensen, S. R. 2007. Chemical markers in Veronica sect. Hebe. II. Biochem. Syst. Ecol. 35, 777-784.

Rønsted, N., Göbel, E., Franzyk, H., Jensen, S. R., Olsen, C. E., 2000.

Chemotaxonomy of Plantago. Iridoid glucosides and caffeoyl phenylethanoid glycosides. Phytochemistry, 55, 337-348.

Stermitz, F. R., Foderaro, T. A., Li, Y. X., 1993. Chemistry of the Scrophulariaceae. 
Part 26. Iridoid glycoside uptake by Castilleja integra via root parasitism on Penstemon teucrioides. Phytochemistry 32, 1151-1153.

Sticher, O., Afifi-Yazar, F. U., 1979. Minecoside and verminoside, two new iridoid glucosides from Veronica officinalis L. (Scrophulariaceae). Helv. Chim. Acta $62,535-539$.

Sticher, O., Meier, B., Lehmann, D., Swiatek, L. 1980. Scrophularioside, a new iridoid glucoside from Scrophularia lateriflora. Planta Med. 38, 246-254.

Strunz, G. M., Giguere, P., Thomas, A. W., 1986. Synthesis of pungenin, a foliar constituent of some spruce species, and investigation of its efficacy as a feeding deterrent for spruce budworm [Choristoneura fumiferana (Clem.)]. J. Chem. Ecol. 12, 251-260.

Stuppner, H. Wagner, H., 1989. Minor iridoid and phenol glycosides of Picrorhiza kurrooa. Planta Med. 55, 467-469.

Sun, X., Shen, G., Tian, X., 2006. Chemical components of Scrofella chinensis (II). Acta Bot. Boreal.-Occident. Sin. 26, 412-415.

Taskova, R., Handjieva, N., Peev, D., Popov, S., 1998. Iridoid glucosides from three Veronica species. Phytochemistry 49, 1323-1327.

Taskova, R. M., Gotfredsen, C. H., Jensen, S. R., 2005. Chemotaxonomic markers in 
Digitalideae (Plantaginaceae). Phytochemistry 66, 1440-1447.

Taskova, R. M., Gotfredsen, C. H,. Jensen, S. R., 2006. Chemotaxonomy of Veroniceae and its allies in the Plantaginaceae. Phytochemistry 67, 286-301.

Vesper, T. Seifert, K., 1994. Iridoids and other glucosides from Penstemon acuminatus. Phytochemistry 37, 1087-1089.

Wagstaff, S. J., Bayly, M. J., Garnock-Jones, P. J., Albach, D. C., 2002. Classification, origin and diversification of the New Zealand hebes (Scrophulariaceae). Ann. Missouri Bot. Gard. 89, 38-63.

Wang, H., Sun, Y., Ye, W.-C., Xiong, F., Wu, J.-J., Yang, C.-H., Zhao, S.-X., 2004. Antioxidative phenylethanoid and phenolic glycosides from Picrorhiza scrophulariiflora. Chem. Pharm. Bull. 52, 615-617.

Yang, X.-D., Yang, L.-J., Yang, S., Zhao, J.-F., Zhang, H.-B., Li, L., 2007. Two new iridoid glycosides from Lagotis yunnanensis. Z. Naturforsch. 62B, 749-752. 
Table $1 .{ }^{1} \mathrm{H}(500 \mathrm{MHz})$ and ${ }^{13} \mathrm{C}$ NMR $(75 \mathrm{MHz})$ spectra of derwentiosides A-C (7-9) in methanol- $d_{4}$.

\begin{tabular}{|c|c|c|c|c|c|c|}
\hline \multirow[t]{2}{*}{ Atom } & \multicolumn{2}{|c|}{ Derwentioside A (7) } & \multicolumn{2}{|l|}{ Derwentioside B (8) } & \multicolumn{2}{|c|}{ Derwentioside C (9) } \\
\hline & ${ }^{1} \mathrm{H}$ & ${ }^{13} \mathrm{C}$ & ${ }^{1} \mathrm{H}$ & ${ }^{13} \mathrm{C}$ & ${ }^{1} \mathrm{H}$ & ${ }^{13} \mathrm{C}$ \\
\hline \multicolumn{7}{|l|}{ Agluc } \\
\hline 1 & $5.18(d, 5.8)$ & 96.5 & $5.15(d, 5.9)$ & 96.5 & $5.15(d, 5.9)$ & 96.6 \\
\hline 3 & $6.32(d d, 6.1,1.8)$ & 141.9 & $6.31(d d, 6.1,1.9)$ & 141.8 & $6.31(d d, 6.1,1.8)$ & 141.7 \\
\hline 4 & $5.11(d d, 6.1,3.6)$ & 105.0 & $5.09(d d, 6.1,3.6)$ & 105.1 & $5.10(d d, 6.1,3.6)$ & 105.1 \\
\hline 5 & $3.06(m)$ & 42.3 & $3.02(m)$ & 42.4 & $3.02(\mathrm{~m})$ & 42.3 \\
\hline 6 & $5.57(m)$ & 85.8 & $5.51(\mathrm{~m})$ & 85.3 & $5.51(\mathrm{~m})$ & 85.3 \\
\hline 7 & $5.93(\mathrm{~m})$ & 125.7 & $5.89(\mathrm{~m})$ & 126.0 & $5.90(\mathrm{~m})$ & 125.9 \\
\hline 8 & & 152.1 & & 151.7 & & 151.6 \\
\hline 9 & 3.13 (br. $t, 6)$ & 48.2 & 3.10 (br. $t, 6)$ & 48.2 & 3.10 (br. $t, 6)$ & 48.0 \\
\hline \multirow[t]{2}{*}{10} & 4.41 (br. $d, 15.6)$ & 61.1 & 4.39 (br. $d, 15.7)$ & 61.1 & 4.40 (br. $d, 15.7)$ & 61.0 \\
\hline & 4.24 (br. $d, 15.6)$ & & $4.22($ br. $d, 15.7)$ & & 4.22 (br. $d, 15.7)$ & \\
\hline \multicolumn{7}{|l|}{ Glc } \\
\hline $1^{\prime}$ & $4.69(d 7.9)$ & 99.7 & $4.68(d, 7.9)$ & 99.7 & $4.68(d, 7.9)$ & 99.6 \\
\hline $2^{\prime}$ & $3.23(d d, 9.0, .7 .9)$ & 74.8 & $3.22(d d, 9.1,7.9)$ & 74.8 & $3.23(d d, 9.0,7.9)$ & 74.6 \\
\hline $3^{\prime}$ & $3.39(\mathrm{~m})$ & 77.8 & $3.38(\mathrm{~m})$ & 77.8 & $3.39(t$-like, 9.0$)$ & 77.6 \\
\hline $4^{\prime}$ & 3.3 obsc. & 71.5 & 3.3 obsc. & 71.5 & 3.3 obsc. & 71.3 \\
\hline $5^{\prime}$ & 3.3 obsc. & 78.2 & 3.3 obsc. & 78.3 & 3.3 obsc. & 78.0 \\
\hline \multirow[t]{2}{*}{$6^{\prime}$} & 3.88 (br. $d, 11.8)$ & 62.6 & 3.87 (br. $d, 11.9$ ) & 62.6 & 3.87 obsc. & 62.5 \\
\hline & $3.66(d d, 11.8,4.8)$ & & $3.65(d d, 11.9,4.6)$ & & $3.66(d d, 11.8,5.1)$ & \\
\hline \multicolumn{7}{|l|}{ Aroyl } \\
\hline $\mathrm{CO}$ & & 167.9 & & 168.0 & & 167.9 \\
\hline $1 "$ & & 131.4 & & 122.3 & & 122.4 \\
\hline 2" & $8.00(d$-like, 7.6$)$ & 130.5 & 7.85 (d-like, 8.8) & 132.8 & $7.50(d, 1.8)$ & 113.6 \\
\hline 3" & $7.49(t$-like, 7.6$)$ & 129.6 & $6.80(d$-like, 8.8$)$ & 116.1 & & 148.5 \\
\hline 4" & $6.62(t$-like, 7.6$)$ & 134.3 & & 163.4 & & 152.6 \\
\hline $5 "$ & $7.49(t$-like, 7.6$)$ & 129.6 & $6.80(d$-like, 8.8$)$ & 116.1 & $6.82(d, 8.2)$ & 115.8 \\
\hline 6" & $8.00(d$-like, 7.6$)$ & 130.5 & 7.85 (d-like, 8.8) & 132.8 & $7.52(d d, 8.2,1.8)$ & 125.0 \\
\hline $\mathrm{OMe}$ & & & & & $3.87(s)$ & 56.3 \\
\hline
\end{tabular}


Table 2. ${ }^{1} \mathrm{H}(500 \mathrm{MHz})$ and ${ }^{13} \mathrm{C}$ NMR $(75 \mathrm{MHz})$ spectra of catarractoside (18) and the model compound $\mathbf{1 7}$.

\begin{tabular}{clccc}
\hline \multicolumn{3}{c}{ Catarractoside (18) } & & $\begin{array}{c}\text { Asystasio- } \\
\text { side E }(\mathbf{1 7})^{\mathrm{a}}\end{array}$ \\
Atom & \multicolumn{1}{c}{${ }^{1} \mathrm{H} \mathrm{MeOD}$} & ${ }^{13} \mathrm{C} \mathrm{MeOD}$ & ${ }^{13} \mathrm{C} \mathrm{D}_{2} \mathrm{O}$ & ${ }^{13} \mathrm{C} \mathrm{D}_{2} \mathrm{O}$ \\
Agluc & & & & \\
1 & $5.63(d, 3.9)$ & 93.0 & 92.7 & 92.6 \\
3 & $6.29(d d, 6.2,1.8)$ & 141.0 & 140.1 & 139.6 \\
4 & $5.07(d d, 6.2,3.6)$ & 105.6 & 105.7 & 106.1 \\
5 & $2.78(m)$ & 36.7 & 34.5 & 35.4 \\
6 & $3.93(d d, 7.9,6.0)$ & 89.7 & 88.3 & 81.1 \\
7 & $4.10(d, 7.9)$ & 71.4 & $69.8 ?$ & 71.6 \\
8 & & 80.4 & 79.7 & 79.3 \\
9 & $2.50(d d, 10.7,3.9)$ & $c a 49$ & 47.1 & 49.1 \\
10 & $3.93(d, 11.7)$ & 64.3 & 63.3 & 62.4 \\
& $3.74(d, 11.7)$ & & & \\
Glc & & & & \\
$1^{\prime}$ & $4.64(d, 8.0)$ & 99.7 & 99.1 & 98.9 \\
$2^{\prime}$ & $3.20(d d, 9.0,8.0)$ & 74.8 & 73.5 & 73.4 \\
$3^{\prime}$ & 3.37 obsc. & 78.0 & 76.5 & 76.4 \\
$4^{\prime}$ & 3.3 obsc. & 71.7 & 70.4 & 70.4 \\
$5^{\prime}$ & 3.3 obsc. & 78.2 & 77.0 & 76.9 \\
$6^{\prime}$ & $3.87(d d 11.6,1.0)$ & 62.9 & 61.5 & 61.5 \\
& 3.65 obsc. & & & \\
Rha & & & & \\
$1^{\prime \prime}$ & $4.91(d, 1.7)$ & 102.8 & 101.8 & \\
$2^{\prime \prime}$ & $3.86(d d, 3.2,1.7)$ & 72.2 & 70.9 & \\
$3^{\prime \prime}$ & 3.65 obsc. & 72.2 & 70.8 & \\
$4^{\prime \prime}$ & $3.3 .40(t, 9.5)$ & 73.8 & 72.8 & \\
$5^{\prime \prime}$ & 3.65 obsc. & 70.5 & 70.1 & \\
$6^{\prime \prime}$ & $1.27(d, 6.2)$ & 18.2 & 17.6 & \\
\hline
\end{tabular}

a) Data from Demuth et al. (1989) 
<smiles>C[C@]1(O)CCC2C(C(=O)O)=COC(O)C21</smiles>

1<smiles>C[C@@H]1[C@H](O)CC2C(C(=O)O)=CO[C@H](O)[C@H]21</smiles>

2<smiles>C=C1C(O)CC2C(C(=O)O)=COC(O)C12</smiles>

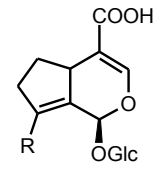

4; $\mathrm{R}=\mathrm{CH}_{2} \mathrm{OH}$

5; $\mathrm{R}=\mathrm{COOH}$<smiles>[R9]C1C=C(CO)[C@H]2C(=O)OC=C[C@H]12</smiles><smiles>[R9]C1C2C=COC(O)C2C2OC12CO</smiles>

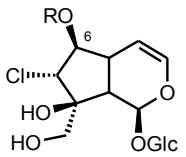

6; $\mathrm{R}=\mathrm{H} ;$ Aucubin

$\begin{array}{ll}\text { 7; } \mathrm{R}=\text { Benzoyl; } & \text { 12; } \mathrm{R}=3,4-\mathrm{diOH}-\text { Benzoy } \\ \text { 8. } \mathrm{R}=\mathrm{p}-\mathrm{OH}-\mathrm{Benzoyl} & 13 \cdot \mathrm{R}=\mathrm{p}-\mathrm{Coumaroyl}\end{array}$

9; $\mathrm{R}=$ Vanilloy

12; $\mathrm{R}=3,4-\mathrm{diOH}-$ Benzoyl

13; $R=p$-Coumaroyl

14; $R=$ Caffeoyl

$10 ; R=\alpha-$ Rhamnopyranosyl $\quad 15 ; R=$ iso-Feruloyl

16; $R=\alpha-$ Rhamnopyranosyl

18; $\mathrm{R}=\alpha-$ Rhamnopyranosyl

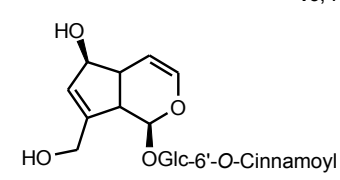

19

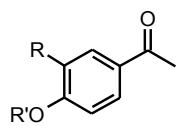

20a; $\mathrm{R}=\mathrm{H} ; \mathrm{R}^{\prime}=\mathrm{Glc}$

20b; $R^{\prime}=H ; R=O G \mid c$

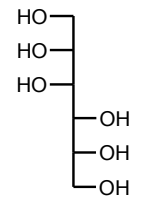

21

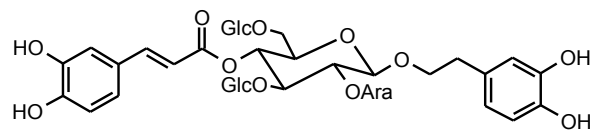

22 